\title{
Patterns of durum wheat response to favorable environments
}

Rozova M.A.

Federal Altai Scientific Centre of Agro-BioTechnologies, Barnaul, Russia

e-mail:mrosova@yandex.ru

Responsiveness is an important part of durum wheat adaptation taking that the crop is usually sown after good preceding crop supplied with major nutrients and moisture. For the period 1985-2018 the yield in competitive yield trails of spring durum wheat in $\mathrm{Ob}$ ' forest-steppe of Altai territory sown after fallow field made up $0.1 \ldots 5.1 \mathrm{t} / \mathrm{ha}$. In 2018 durum wheat produced the highest yield for the time being $-5.6 \mathrm{t} / \mathrm{ha}$. In previous four years the yield of the same set of genotypes made up $3.3 \mathrm{t} / \mathrm{ha}$. The rise of yield was accompanied with the increase of the number of spikes per plant $(+55 \%)$, aboveground plant weight $(+85 \%)$, grain weight of main spike $(+52 \%)$, grain weight of side spikes $(+135.3 \%)$, grain weight per plant $(+120 \%)$. Number of kernels per spike and 1000 kernel weight increased less $+17.6 \%$ and $+27.2 \%$ respectively. Parameters of crop density either were similar (spikes/1 $\mathrm{m}^{2}$ ) or lower (plants/1 $\mathrm{m}^{2}$ ) than in previous years. A mid-ripening line Hordeiforme 881 and a mid-late line Hordeiforme 748 were top-yielders with grain yield 6.90 and $6.47 \mathrm{t} /$ ha that was 1.22 and $0.81 \mathrm{t} / \mathrm{ha}$ higher that corresponding checks had. They have advantage in above-ground plant weight, grain weight of main and side spikes and plant as a whole and a number of kernels per spike. Hordeiforme 881 produced kernels $4.5 \mathrm{~g}$ larger than check variety. Low-yielding genotypes in favorable environments did not reach mean yield because of the lower level of a complex of related traits with largest impact of plant weight and grain weight of side spikes. Old local varieties made the majority of the group. 